\title{
Market discipline: a review of the Mexican deposit market
}

\author{
Edgar Demetrio Tovar-García
}

Received: 8 October 2013/Revised: 6 December 2013/Accepted: 13 March 2014/

Published online: 15 April 2014

(C) The Author(s) 2014. This article is published with open access at Springerlink.com

\begin{abstract}
This paper studies the mechanisms of market discipline in the Mexican deposit market. It tests the hypothesis that low-quality banks pay higher interest rates on deposits, receive fewer deposits, and shift their deposit agreements from long to short term. This hypothesis was assessed with positive evidence in Mexico during the period 1991-1996, but was not checked again. This research uses a dynamic panel model and a sample of 37 banks from December 2008 to September 2012 to re-evaluate the market discipline hypothesis. The findings suggest a weak presence of discipline induced by depositors. Principally, market discipline is absent within market sectors.
\end{abstract}

Keywords Market discipline $\cdot$ Deposit market $\cdot$ Bank risk $\cdot$ Mexico

JEL Classification E59 - G21 - G39

\section{Introduction}

It is possible that a common depositor cannot interpret indicators about the risky behavior of his/her bank. Consequently, the bank possesses better information about its activities and its probability of failure, that is, a moral hazard problem would exist. It seems that ordinary depositors are not involved with this. Nevertheless, principally during the last 10 years, academics and the Basel Committee have proposed disclosing banking information and providing depositors and other economic agents with better information about bank fundamentals in order to react

\footnotetext{
E. D. Tovar-García $(\bowtie)$

National Research University "Higher School of Economics” (HSE), Myasnitskaya Street, 20, Moscow 101000, Russia e-mail: beno09@yahoo.com; etovar@hse.ru
} 
to riskier behavior of banks through market forces (prices and quantities). This is known as the third pillar of Basel III: market discipline.

Márquez (2011) points out that small depositors are strongly influenced by marketing, and that they do not take into account bank fundamentals in order to decide where to allocate their resources. On the contrary, larger depositors, representing the largest percentage of total deposits, should monitor the risk taking of their banks. Disclosure of banking information will alleviate information asymmetry problems and financially educated agents, who, as we can expect are the larger depositors, will be able to monitor their banks particularly well.

The Diamond and Dybvig (1983) model shows withdrawals of deposits as a response to higher probabilities of bank failure, which can cause bank runs with strong depressive effects on the economy. Accordingly, government intervention through deposit insurance schemes is attractive, because it allows better sharing of risk and prevents bank panic. However, deposit insurance can weaken market discipline; many empirical studies supporting this undesirable consequence can be found in the literature (Demirguc-Kunt and Huizinga 2004). In addition, other explicit and implicit policies, such as the too-big-to-fail policy, appear to negatively affect the monitoring activities of economic agents. As a result, some depositors believe that their money in a bank account is free of risk, and they simply do not monitor their banks. In addition, some banks may believe that the monetary authorities will bail out them, creating incentives for riskier behavior. Therefore, "where bank runs are explained by bank fundamentals, there is a strong argument for providing depositors with adequate bank fundamentals' information" (Goday et al. 2005: 2).

Under these conditions, it is necessary to test the presence of market discipline, to support disclosure policy, and to verify if the monetary authorities send clear signals about government involvement in the case of bank failure. This would also remind depositors and other economic agents that they have an important role in maintaining a sound banking system.

The market discipline hypothesis has been extensively tested around the world. The major findings suggest that the depositors discipline their banks by demanding higher interest rates on deposits from riskier banks or withdrawing their resources. Thus, this research is motivated by the following question: which mechanisms of market discipline do Mexican depositors use to regulate the risky behavior of their banks?

Mexico is an interesting case. Seven banks currently manage around $80 \%$ of assets and $85 \%$ of deposits, and its banking system was expropriated in 1982 due to the debt crisis, privatized in 1991 and bailed out in 1997 soon after the so-called Tequila crisis in 1994 and 1995. Martinez-Peria and Schmukler (2001) found evidence in favor of the market discipline hypothesis in the deposit market, especially after the Tequila crisis, even with the deposit insurance scheme. This hypothesis was not checked again, although Tovar-García (2012) also found evidence of market discipline from the asset side; that is, borrowers discipline their banks by paying higher interest rates to high-quality banks, but the largest banks and retail banks are exempt from this discipline. In addition, the subordinated debt is 
considered to be a key instrument in exerting market discipline (Calomiris 1999). However, only a few Mexican banks issued this kind of obligation. Consequently, there are reasonable grounds for evaluating once again the presence of market discipline in the Mexican deposit market.

The rest of the paper is organized as follows. Section 2 discusses in brief the theory of market discipline and presents the major findings of empirical studies for Latin American countries. Section 3 describes the data sets, a sample of 37 Mexican banks from December 2008 to September 2012. Section 4 specifies econometric models (dynamic panel models with the SYS GMM estimator) and it reports and discusses the results. Finally, conclusions, recommendations, and proposals for future research are outlined.

\section{Brief review of literature}

The well-known orthodox theory of supply and demand is behind the market discipline hypothesis. In banking markets, economic agents should react to the riskier behavior of their banks, because their costs may present a direct relationship with bank risk taking. Thus, the riskier behavior of a particular bank will change depositors' preferences, and they will shift the supply curve of deposits toward the left, requiring higher interest rates on deposits or/and withdrawing their resources. As a result, this particular bank should modify its risk taking. We assume that depositors can monitor and indentify riskier banks, and they react in consequence. In other words, market discipline shows two faces: the ability to monitor bank conditions and the ability to influence banks' actions, market monitor and market influence in terms of Flannery (2001).

In the deposit market, it is possible to identify three mechanisms used by depositors to regulate the risky behavior of their banks. First, the price-based mechanism: depositors request higher interest rates on deposits as a response to riskier behavior of their banks. Second, the quantity-based mechanism: depositors withdraw their funds as a response to risky behavior. In the empirical literature, these are the most popular mechanisms of market discipline, and also it is possible to recognize a third mechanism, maturity based, where depositors shift their resources from long- to short-term deposits due to the riskier behavior of their banks (Goday et al. 2005; Murata and Hori 2006; Semenova 2007). This gives a warning about the capability of the depositor to easily withdraw resources as a response to excessive risk. The baseline model to test these mechanisms can be written as (1):

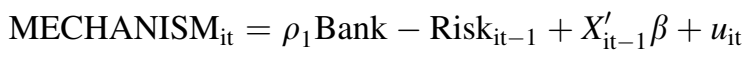

MECHANISM is a measure of the interest rate on deposits (price based), a measure of the amount of deposits (quantity based), or a measure of time terms (maturity based). The main explanatory variable is bank risk, usually based on the five categories of the CAMEL methodology: capital adequacy, asset quality, management quality, earnings and liquidity. $X$ represents other control variables. Thus, a significant coefficient of bank risk, with the theoretical expected sign, indicates the presence of market discipline. 
Table 5, in the appendix, shows empirical studies about market discipline induced by depositors in Latin American countries. In that table the reader can easily identify the sample, period of analysis, methodology, main dependent and independent variables, and major findings. In Latin America, in general, empirical evidence confirms the presence of market discipline in the deposit market, despite the existence of deposit insurance. Each empirical study presents particularities, for example, Márquez (2011) finds that small depositors do not exert discipline in Colombia. Romera and Tabak (2010) point out that Brazilian depositors consider that large banks are safer than small banks; therefore, the largest banks do not experience discipline and the implicit "too-big-to-fail" policy is supported by the government. In Uruguay, Goday et al. (2005) highlight that the quantity mechanism is more relevant than the price mechanism, which is a common result for emerging economies, where asymmetric information problems can bias the price mechanism.

In Chile (Bundevich and Franken 2003) and Costa Rica (Mayorga-Martínez and Muñoz-Salas 2002), weak evidence was found in favor of the market discipline hypothesis. Baquero-Latorre (2000) concludes that there is no evidence of market discipline in Ecuador. In addition, tests on market discipline have been re-evaluated in Chile, Argentina, Colombia and Uruguay (see Table 5, in the appendix).

In general, and in particular for Latin America, one of the most significant empirical studies on market discipline was elaborated by Martinez-Peria and Schmukler (2001), who found evidence of market discipline during the 1980 and 1990s by quantity and price mechanisms in Chile, Argentina and Mexico, even with deposit insurance, and predominantly in the aftermath of crises. For Mexico, the regressions included principally 12 of the most important Mexican banks providing:

...evidence that deposits respond to bank risk, particularly in the post-crisis period. During this period, banks with higher returns on assets, higher capital over assets, and a higher proportion of personal loans attract more deposits. Bank risk characteristics are not significant in the pre-crisis and crisis periods. On the other hand, the evidence suggests that interest rates do respond to bank risk taking throughout the three periods. A higher proportion of nonperforming loans raises the interest rates paid by banks. A rise in the cash-toassets ratio and the capital-to-assets ratio reduce the interest rates charged to banks. Banks that increase the return on assets and the proportion of personal loans and real estate loans pay lower interest rates. The $F$ tests indicate that bank fundamentals are generally jointly significant. (p. 1043).

Historically, the presence of market discipline in the Mexican deposit market was verified by Luce (2000) and Huybens et al. (2005), who found that bank fundamentals were a strong determinant of bank withdrawals and acceptability of bank notes during the years 1900-1910, including the financial crisis of 1907, and in spite of the regulatory framework with an implicit and limited deposit insurance.

It is interesting to note that the majority of the empirical studies do not test banks' reactions, that is, the hypothesis of market influence. Based on Calomiris and Powell (2000), there are some studies testing whether the interest rate on deposits reverts to its mean, or whether bank fundamentals are explained by changes in the amount of deposits or interest rate, as a response of the bank to market discipline 
induced by depositors (Barajas and Steiner 2000; Goday et al. 2005; Galindo et al. 2005). First, endogeneity concerns are evident, and second, in these studies the banking response may be a result of pressures from regulators, or other market factors, which cannot be controlled or measured. Accordingly, the tests of market discipline (tests of market monitor) simply assume that banks will respond to market forces.

In this context, this paper contributes to the empirical literature in three ways. First, it tests the third mechanism of market discipline: maturity based, which has not been tested before in the Mexican deposit market. Second, it analyses groups of banks by market sector and uses a large diversity of independent variables to check robustness. Third, it employs panel data in a dynamic model with a SYS GMM estimator (Blundell and Bond 1998) that has not been utilized before to test discipline in the Mexican deposit market.

\section{Data}

The data employed in this research are drawn from the historical statistics of the National Banking and Securities Commission (CNBV), covering the period December 2008 to September 2012 (quarterly), during the crises in the USA and Europe. In this period, Mexico had negative GDP growth rates particularly in 2009 and positive rates in 2010-2012.

I analyze 4 years with 16 observations because of data limitations. Baseline data are incomplete for many key indicators, and this period of analysis presents more complete statistics, covering 37 banks (Mexico currently has 44 banks in operation, two were founded in 2012 and information for five investment banks was unavailable). In addition, I expect that Mexican depositors carefully monitored their banks during the years of analysis, in accordance with the wake-up call, as proposed by Martinez-Peria and Schmukler (2001: 1050), "traumatic events teach depositors that they should be concerned about the safety of their deposits at all times". It is important to notice that this period includes limited deposit insurance, and bank depositors are exposed to the possibility of loss. Nowadays the Bank Savings Protection Institute, known by its Spanish acronym, IPAB, provides limited insurance, around 1.9 million Mexican pesos per depositor and bank. On the contrary, during the years analyzed by Martinez-Peria and Schmukler (2001) the Fund for the Protection of Bank Savings, known by its acronym, FOBAPROA, implicitly protected $100 \%$ of deposits.

\subsection{Measures of the mechanisms of market discipline}

To test the price-based discipline mechanism in the deposit market I use as dependent variable an implicit interest rate: the ratio of 12-month interest payments on deposits to the amount of annual average deposits (IIRDE). It is important to notice that the implicit interest rates have been widely employed in the literature on market discipline due to data limitations; it is complicated to find data directly 


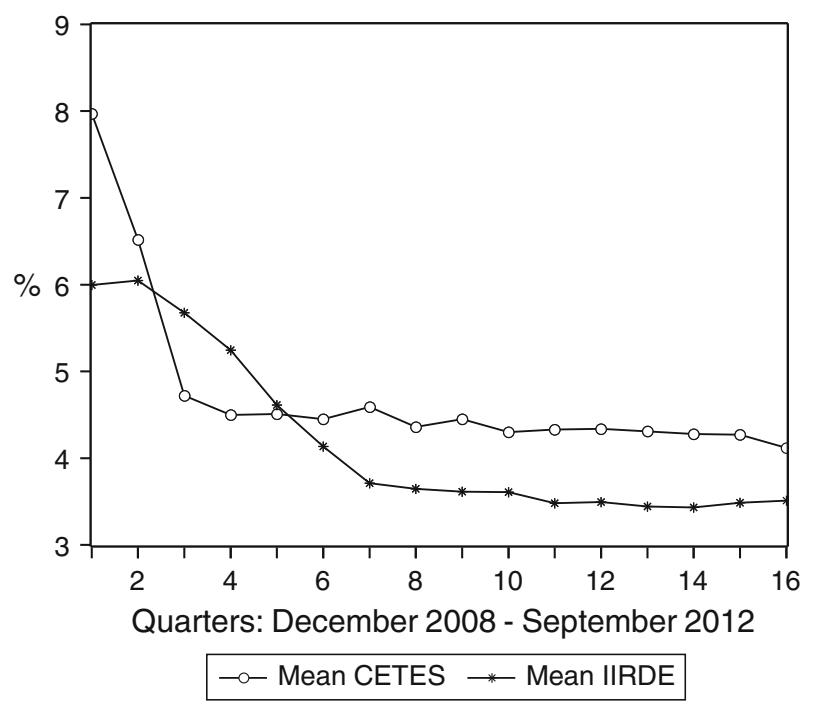

Fig. 1 Mexican federal treasury certificates (CETES) and implicit interest rate on deposits (IIRDE)

describing the interest rate on deposits. To evaluate the performance of IIRDE, I compare it with the 28 days CETES (Mexican Federal Treasury Certificates).

Figure 1 shows the CETES and the average at quarter end of IIRDE. In general, both rates follow similar trends, but from March 2009 to December 2009 the banks, on average, paid rates above the reference rate, and from March 2010 to September 2012 paid rates below the CETES. The correlation between CETES and IIRDE is 0.38. Thus, the Central Bank of Mexico (Banxico) may influence the interest rate on deposits, but market factors strongly pressure the rates effectively paid by banks.

It is important to recognize that in the presence of imperfect information the price-based mechanism might be biased (Park 1995; Park and Peristiani 1998). Accordingly, the growth rate of deposits (GROWTHDE: deposits $/$ /deposits last-quarter $_{\text {) }}$ ) is used as a dependent variable to test the quantity-based discipline mechanism, that is, whether low-quality banks receive fewer deposits in comparison with highquality banks. This measure is used because absolute amounts can be influenced by bank characteristics such as size and business orientation.

Furthermore, I explore the third discipline mechanism: maturity based. Do riskier banks obtain more short-term deposits? Note that depositors can shift from long- to short-term agreements as a response to riskier behavior of their banks, and this shift is measured by subtraction: the long-term deposits minus the short-term, both expressed as a proportion of the total deposits (MATURITYDE). Higher values of MATURITYDE should reflect high-quality banks. In the Mexican case, in September 2012 the long-term deposits represented around $40 \%$ of total deposits, and the short-term $60 \%$. The largest Mexican banks operated $80 \%$ of long-term deposits. 


\subsection{Measures of bank risk or bank fundamentals}

The first models testing discipline in the deposit market utilized, as a first step, bank fundamentals to elaborate a measure of the probability of bank failure, and as a second step employed that measure as an explanatory variable of the mechanisms of market discipline. In the literature, bank ratings (Fitch, Moody's, Standard and Poor's, etc.) are popular explanatory variables, too. However, I will not include this kind of variable due to data limitations. These ratings are available for only a few Mexican banks (the largest and listed banks). In addition, these ratings show low variability, and were criticized during the last global financial crisis because they did not provide accurate information about risk taking.

The latest empirical studies employ directly bank fundamentals to understand which variables (or types of risk) are influencing market discipline. Accordingly, in this research the key explanatory variables are approached using the capital adequacy, asset quality, management quality, earnings and liquidity (CAMEL) system.

Capital adequacy is measured by the ratio of capital to total assets (CAPITALR). For asset quality, I use reserve for loan losses (RESERVE) defined as the balance at quarter end of provisions for possible credit losses divided by non-performing loans, and non-performing loans divided by total loans (DOUBTFUL); for management quality, the ratio 12-month managerial expenses to annual average total assets (MANAGEMENT1) and the ratio 12-month managerial expenses to 12-month total income (MANAGEMENT2). Earnings are measured with the 12-month return on assets (ROA) and the 12-month return on capital (ROE), and for liquidity, I use the ratio short-term (circulating) assets to total assets (LIQUIDITY1) and the ratio short-term assets to short-term liabilities (LIQUIDITY2).

In addition, the $Z$ SCORE is used as explanatory variable, defined as the 3-year average of the 12-month ROA plus the 3-year average ratio of CAPITALR, divided by the 3-year standard deviation of ROA. This indicator has been extensively employed in the literature to measure the bank risk of insolvency (Distinguin et al. 2013). A higher $Z$ SCORE value indicates a lower probability of bank failure, that is, low-risk bank.

Previous empirical studies found that the bank's size is a relevant explanatory variable; therefore, this investigation employs the logarithm of total assets (SIZE) and subsamples to account for the size effect.

Recently, Ben-David et al. (2013) did not find evidence in favor of the market discipline hypothesis in the USA, and pointed out that deposit rates were significantly determined by demand-side factors. Banks increase interest rates in order to attract deposits, particularly when they increase their lending activity. Consequently, I use the banks' loan growth (LOAN) as a key control variable.

\subsection{Descriptive statistics and subsamples of banks}

Summary statistics of the mentioned variables can be seen in Table 1. As TovarGarcía (2012), this investigation uses four bank subsamples to take into account their nature. The first subsample contains seven of the largest banks (G7), which in 


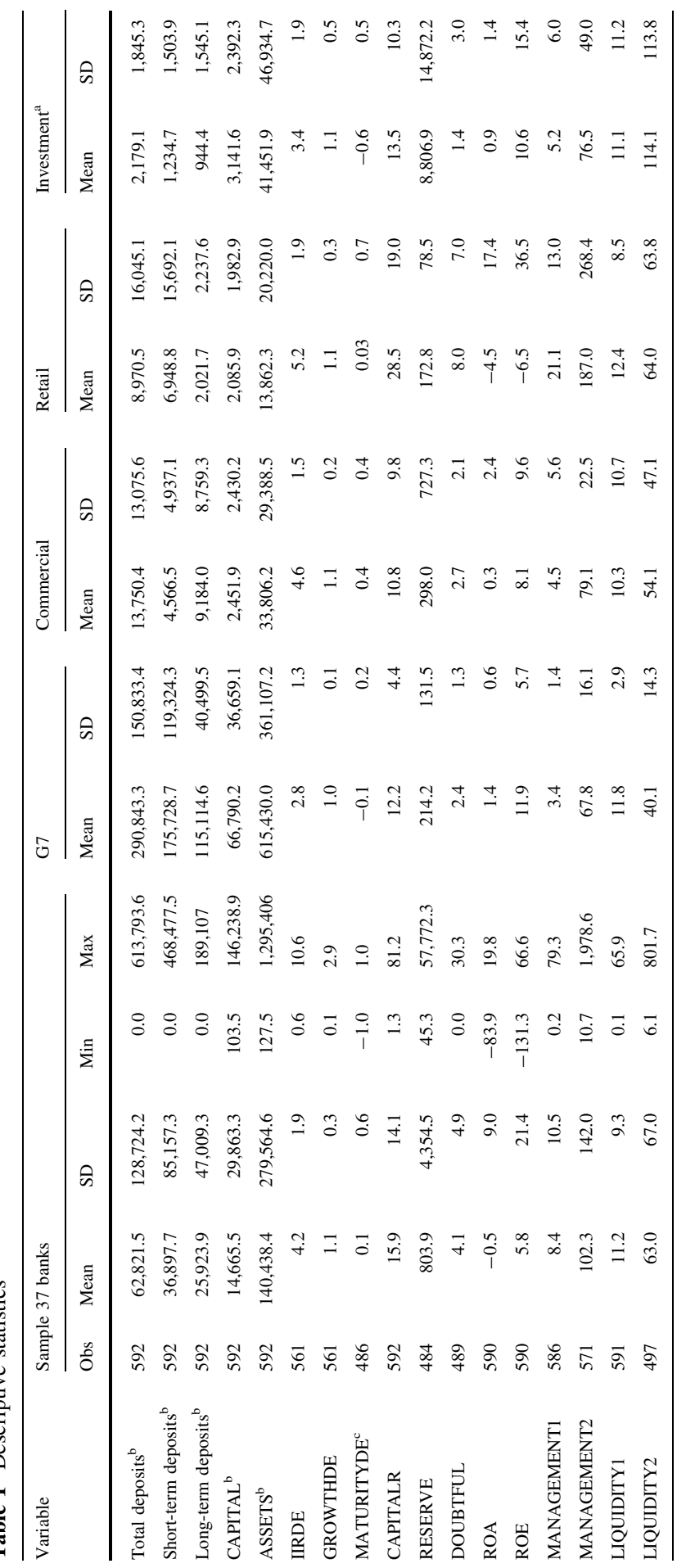

\section{Springer}




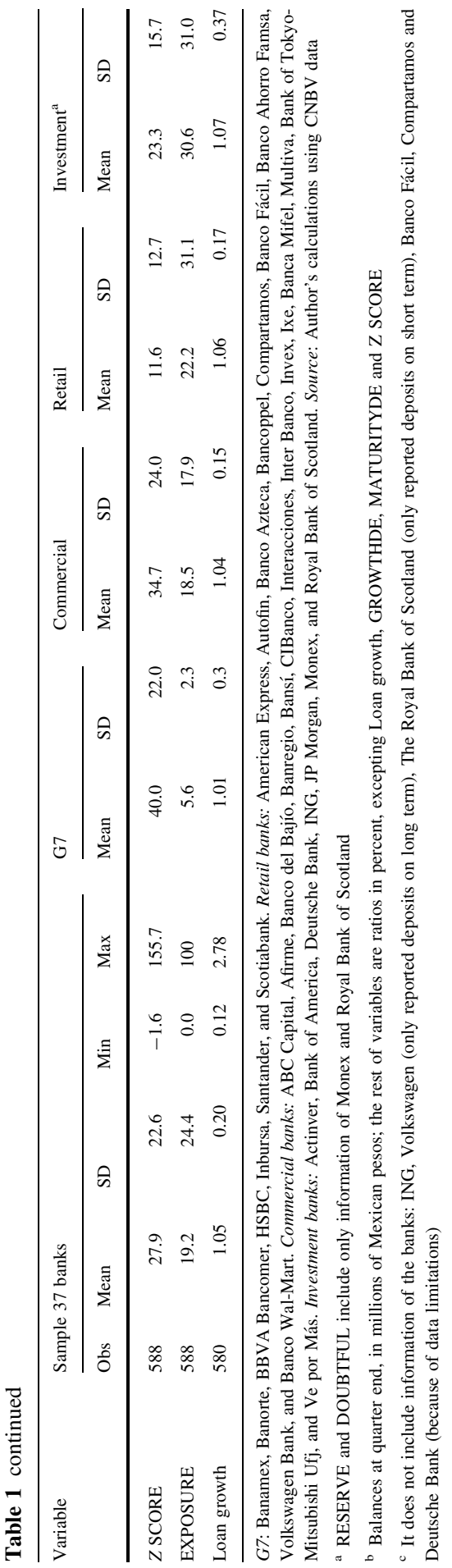


September 2012 attracted around $85 \%$ of total deposits in the banking system. The second subsample includes 14 commercial banks with typical activities, but smaller than the G7. The third subsample includes nine retail banks, which specialize in transactions with consumers. Finally, the fourth subsample contains seven investment banks, working on the issuance of securities.

On average, the G7 banks are around 30 times larger (by total assets) than the other types of bank. However, capital ratios (CAPITALR) show that the G7 banks are below the mean, better than commercial banks, but in a bad position in comparison with retail banks, which show the highest ratios.

On average, IIRDE (the implicit interest rate) equals $4.2 \%$ and the G7 and investment banks are below the mean, that is, they paid lower rates on deposits in comparison with retail and commercial banks, which are above the mean. The GROWTHDE equals 1.1 and practically all types of bank have similar growth rates, but the higher standard deviation corresponds to investment banks. MATURITYDE equals 0.1 ; it means that, in general, $55 \%$ of deposits correspond to long-term agreements, and $45 \%$ to short-term. Note that this calculation did not include information from banks reporting only deposits on short or long term. The G7 and investment banks particularly attracted deposits on short term, unlike commercial banks attracted deposits on long term.

On average, ROA and ROE are negative in the case of retail banks. The indicators of management quality also show that these banks are in the worst positions, but they are above the mean in indicators about liquidity. The highest values of ROA and ROE correspond to the G7. Investment banks show a very good position in the variable LIQUIDITY2 (ratio short-term assets to short-term liabilities). In addition, they show better values than the rest of banks in the variables RESERVE and DOUBTFUL, but this result must be treated with caution, because these variables include information only from two banks.

On average, $Z$ SCORE equals 27.9, the G7 and commercial banks are above the mean, that is, they are banks less risky, in contrast to retail and investment banks, which are below the mean, as we can expect due to the nature of their portfolios.

The correlation matrix (see Table 6 in the appendix) shows relevant positive relationships among total assets, capital and the amount of deposits, in line with previous findings about the relevance of the largest banks in the deposit market. The CAMEL indicators show some high correlations among them (unsurprisingly); therefore, in the regression analysis these variables are included with prudence, to avoid problems of multicollinearity. In the appendix, Fig. 2 shows means and general trends of these variables.

\section{Empirical models}

This research uses regression analysis to test the market discipline hypothesis. Note that the dependent and independent variables might face problems of endogeneity, because of measurement error, omitted variables, and reverse causality. Consequently, it is necessary to use instrumental variables, which is a complicated task due to data limitations. For that reason, previous studies employed lags of 
independent variables as instruments. In addition, the dependent variables are autoregressive. Under these conditions, a dynamic panel data model is attractive (Goday et al. 2005), and a first option is the DIF GMM estimator of Arellano and Bond (1991). However, with small samples, it is recommended to employ the SYS GMM estimator of Blundell and Bond (1998). This allows for lagged values of the dependent variable to be entered as regressors and it uses lags of independent variables in first differences and in levels as instruments correcting endogeneity. It is assumed that the error term is not serially correlated and Sargan's overidentification test validates the instruments.

\subsection{Price-based mechanism}

The Model (2) tests the price-based mechanism of market discipline. The dependent variable is the implicit interest rate on deposits (IIRDE), and the key explanatory variables are lagged by one-quarter to account for the fact that the information is available to the depositors with a certain delay. In addition, the variables are transformed in logarithms, consequently the coefficients measure elasticities, and the model achieves linearity.

$$
\begin{aligned}
\text { LnIIRDE }_{\mathrm{it}}= & \text { LnCAMEL }, \text { and ZSCORE }_{\mathrm{it}-1}^{\prime} \beta+\gamma_{1} \text { SIZE }_{\mathrm{it}-1}+\gamma_{2} \text { LnLOAN }_{\mathrm{it}-1} \\
& +\gamma_{3} \text { EXPOSURE }_{\mathrm{it}-1}+\gamma_{4} \text { CETES }_{\mathrm{t}}+\text { BANK }_{\mathrm{t}}^{\prime} \alpha+T_{t}^{\prime} \tau+u_{\mathrm{it}}
\end{aligned}
$$

The CAMEL variables are included in the model taking into account collinearity among them, and with $Z$ SCORE. SIZE is controlling bank size. LnLOAN is the logarithm of loan growth, controlling the demand effect on interest rates. EXPOSURE is the ratio of interbank borrowing to total deposits, controlling the participation of an individual bank in the interbank deposit market, which may work as a substitute for retail deposits. The reference interest rate CETES controls a possible influence of the monetary authority on the market, and other systemic risks. BANK is a dummy variable for each type of bank (G7, Commercial, Retail and Investment), where the G7 is the reference group, thus the model controls for other bank characteristics and markets. $\mathrm{T}$ is a dummy variable for years controlling effects of unspecified macroeconomic and financial market conditions, which are assumed to be constant across banks.

The central hypothesis of interest is that IIRDE is higher for banks showing lowquality bank fundamentals (higher bank risk). That is, the price paid on deposits (IIRDE) depends inversely upon the level of CAPITALR, RESERVE, ROA, ROE, LIQUIDITY1-2, and Z SCORE, and positively upon the level of DOUBTFUL and MANAGEMENT1-2. This is interpreted as evidence of market discipline in the deposit market through the price mechanism.

Table 2 summarizes the main results. In columns there are regressions using the complete sample and subsamples. The explanatory variables in rows and empty cells indicate that the variable was dropped because of collinearity (read each regression vertically). The majority of regressions pass the Sargan and the serial correlation tests. In addition, the dynamic model is justified, particularly for the 


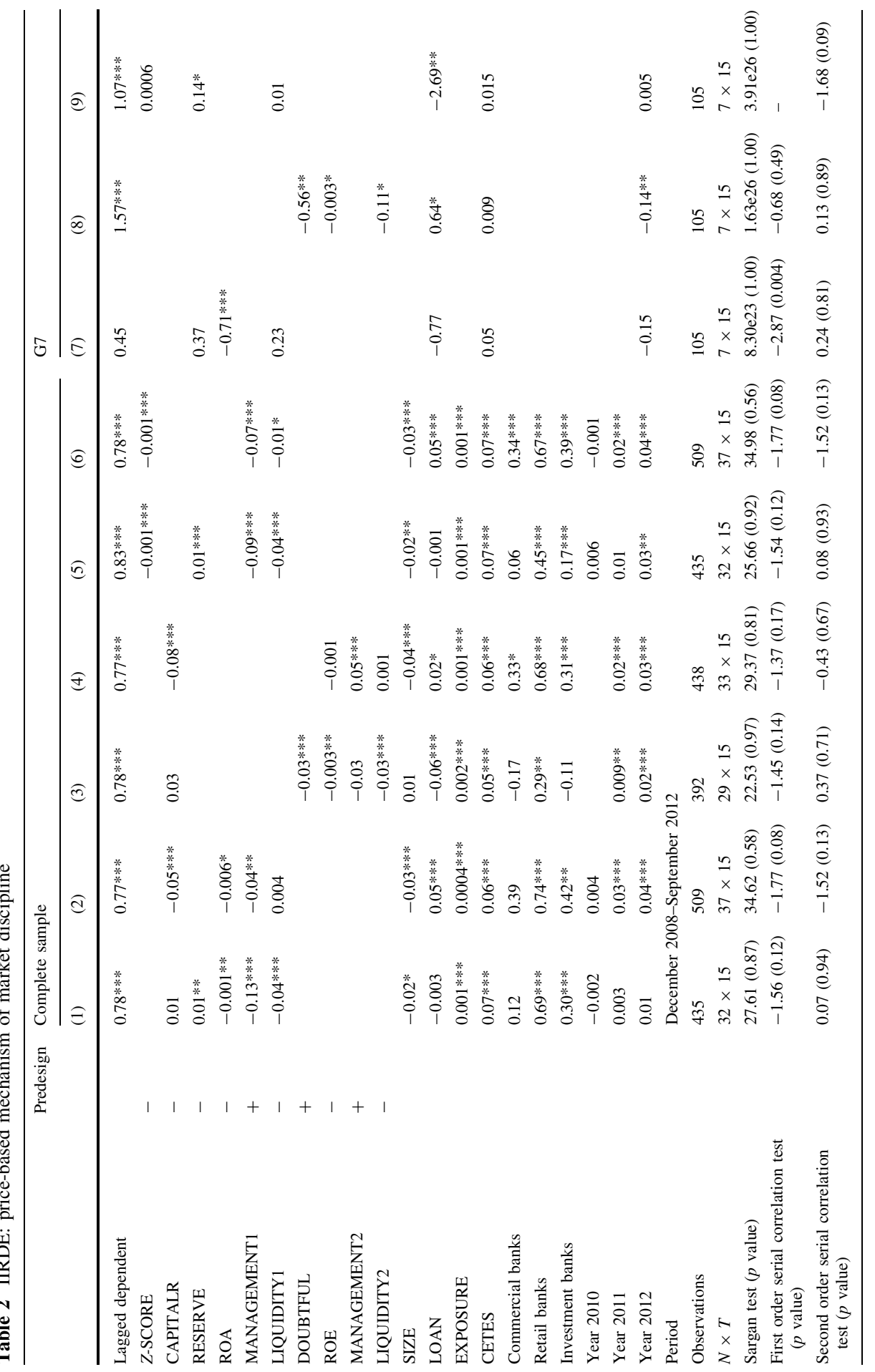




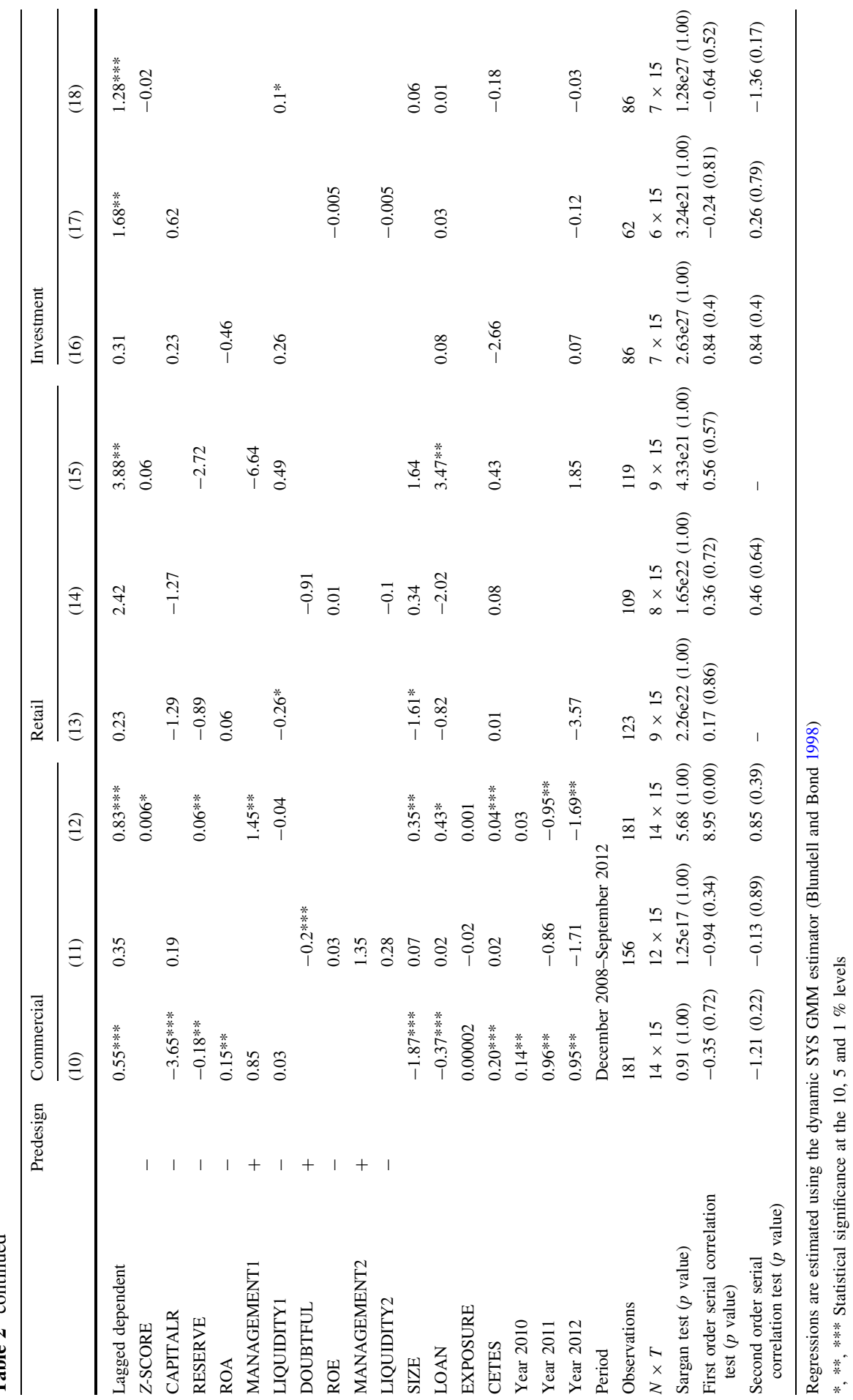


complete sample, the dependent variable as regressor enters with statistically significant coefficients at the $1 \%$ level, see columns (1-6) in Table 2.

In general, the findings show evidence in favor of the market discipline hypothesis through the price-based mechanism. Analyzing the results for the complete sample we can see in Table 2, columns (1-6), that CAPITALR, ROA, ROE and LIQUIDITY1-2 show evidence in accordance with the main hypothesis, although they lack robustness (in some regressions their coefficients lost significance). $Z$ SCORE enters in the regressions with statistically significant coefficients, with the expected sign, and robustness. Therefore, depositors react to market forces taking into account capital adequacy, earnings, and liquidity of their banks. In addition, depositors monitor the risk of insolvency ( $Z$ SCORE). Banks presenting lower levels in these indicators pay higher interest rates on deposits, and vice versa.

Nevertheless, MANAGEMENT1 significantly enters in the regressions, but with the opposite to the expected sign, that is, banks with low-quality management pay lower interest rate on deposits. Moreover, RESERVE and DOUBTFUL show robust evidence against the market discipline hypothesis; they enter in the model with statistically significant coefficients and with the contrary expected sign. In other words, through the price-based mechanism, depositors do not care about the administrative efficiency and the asset quality of their banks.

The control variables show some interesting results. SIZE presents negative and significant coefficients; consequently larger banks pay lower interest rates on deposits (in favor of the implicit "too-big-to-fail" policy). LOAN presents some positive and significant coefficients, that is, there is a demand effect determining interest rates on deposits, as proposed by Ben-David et al. (2013). EXPOSURE enters with positive signs and significance; therefore, a higher exposure to the interbank deposit market corresponds to a higher interest rate on deposits. CETES presents positive signs and significance, predictably, because of the natural relationship between IIRDE and CETES (see Fig. 1). The time dummies show some positive and significant coefficients, surprisingly, because IIRDE shows a negative trend during the period of analysis (see Fig. 2 in the appendix). Probably, CETES is catching up with this trend.

The dummy variables for retail and investment banks show significant and positive coefficients, that is, they pay higher rates in comparison with the G7 banks. This finding also indicates a bias by subsamples of banks. Accordingly, the regressions by subsamples are in columns (7-18), in Table 2.

The model lost meaning in the cases of retail and investment banks, columns (13-18). Many key explanatory variables show coefficients without statistical significance. This suggests that these banks do not experience market discipline within their market sectors. The G7 and commercial banks present estimations in accordance with the findings for the complete sample, but the results lost robustness. For example, a depositor, comparing only the G7 or commercial banks, does not take into account the risk of insolvency; $Z$ SCORE is not significant in the case of the seven largest banks, and for commercial banks $Z$ SCORE presents the opposite to the expected sign. Bank earnings (ROA and ROE) have significance and the expected sign for the G7 group. On the contrary, in the subsample of commercial banks these indicators present the opposite to the expected sign. Consequently, the 
evidence in favor of the market discipline hypothesis through the price mechanism can be considered weak.

\subsection{Quantity-based mechanism}

The Model (3) tests the quantity-based mechanism of market discipline. The dependent variable is the GROWTHDE in logarithms. This model also uses onequarter lag and logarithmic transformation of the key explanatory variables.

$$
\begin{aligned}
\text { LnGROWTHDE }_{\mathrm{it}}= & \text { LnCAMEL, and ZSCORE }_{\mathrm{it}-1} \beta+\gamma_{1} \text { SIZE }_{\mathrm{it}-1}+\gamma_{2} \text { LnLOAN }_{\mathrm{it}-1} \\
& +\gamma_{3} \text { EXPOSURE }_{\mathrm{it}-1}+\gamma_{4} \text { CETES }_{\mathrm{t}}+\text { BANK }_{\mathrm{t}}^{\prime} \alpha+T_{\mathrm{t}}^{\prime} \tau+u_{\mathrm{it}}
\end{aligned}
$$

Again, the CAMEL variables are included in the model taking into account collinearity among them, and with $Z$ SCORE. The control variables have similar functions to the Model (2). The central hypothesis of interest is that GROWTHDE is lower for banks with low-quality bank fundamentals. The amount of deposits, that an individual bank can attract, depends positively upon the level of CAPITALR, RESERVE, ROA, ROE and LIQUIDITY1-2, and inversely upon the level of DOUBTFUL and MANAGEMENT1-2. This is interpreted as evidence of market discipline through the quantity mechanism.

Table 3 summarizes the main results. The majority of reported estimations pass the Sargan and the serial correlation tests. The dependent variable as regressor presents negative coefficients, that is, preceding deposit growth rates impact negatively on future rates.

In the analysis of the complete sample (columns 1-6), the key explanatory variables present some mixed results. CAPITALR enters in the model with the expected sign, with statistically significant coefficients, and robustness. RESERVE and ROE also present the predicted sign and significance, but without robustness, note that DOUBTFUL is statically significant with the contrary expected sign, and ROA does not have statistical significance. Subsequently, to regulate the risky behavior of banks through the quantity mechanism Mexican depositors take into account capital adequacy.

MANAGEMENT1-2 and LIQUIDITY1-2 enter in the regressions with the contrary sign and with statistical significance, that is, banks with low efficiency and liquidity problems can attract more deposits, in opposition to the market discipline hypothesis. Moreover, the risk of insolvency ( $Z$ SCORE) does not have statistical significance.

The bank size enters in the regressions with some significant and negative coefficients, that is, larger banks attract fewer deposits (they show lower deposit growth rates). LOAN enters with positive and significant coefficients, that is, higher loan growth rates positively influence deposit growth rates. EXPOSURE presents negative and significant coefficients, because the interbank deposits are substitutes of retail deposits. CETES has some positive and significant coefficients, that is, higher prices of the Mexican obligations favor the growth of deposits, the CETES rate and the interest rate on deposits present a direct relationship. The time dummies 


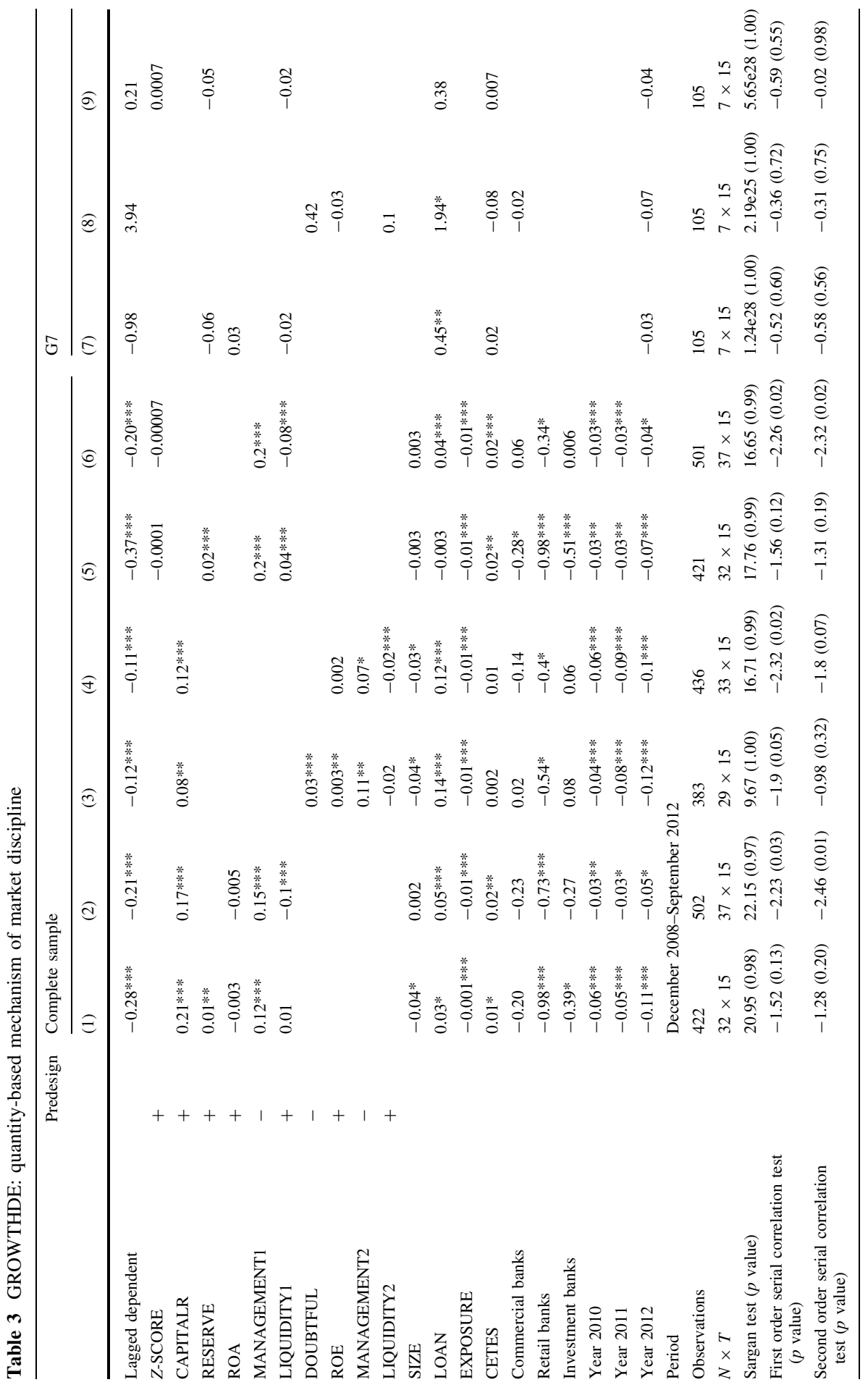




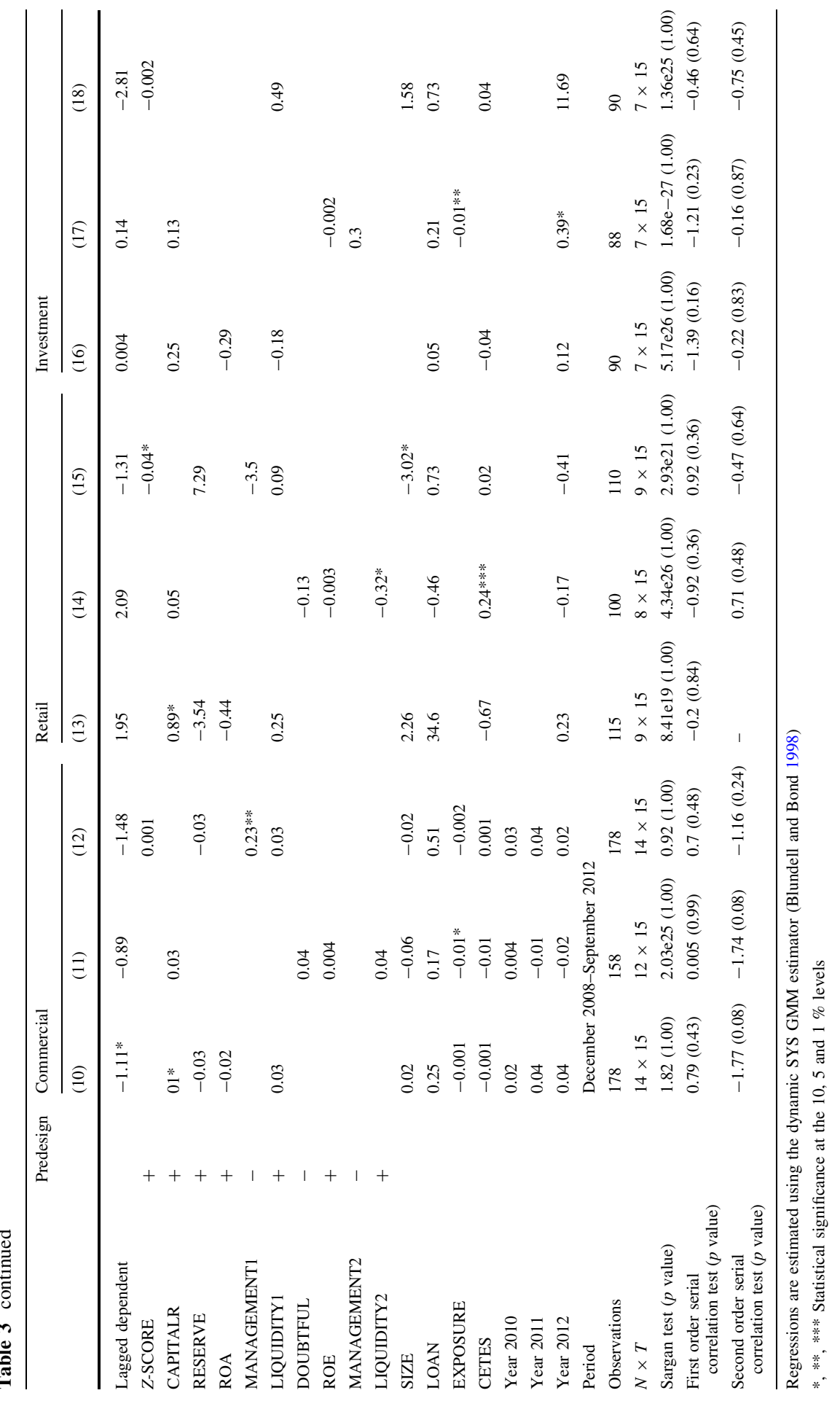


have negative and significant coefficients, in accordance with the general trend of GROWTHDE during the period of analysis (see Fig. 2 in the appendix).

The dummy variables for retail and investment banks show some significant and negative coefficients, that is, they attract fewer deposits in comparison with the largest banks (G7). Nevertheless, in the case of the subsamples (columns 7-18) the model practically lost its meaning. The coefficients of the dependent variable as regressors are not statistically significant. In other words, by groups of banks (market sectors) the attracted deposits do not depend on previous deposits. Furthermore, by subsamples, practically nothing is explaining the amount of attracted deposits; only a few independent variables are statistically significant.

\subsection{Maturity-based mechanism}

The Model (4) tests the maturity-based mechanism of market discipline. The dependent variable is the shift from long- to short-term agreements in the deposit market (MATURITYDE). This analysis excluded banks that attracted only short- or long-term deposits (see Table 1). Once more, one-quarter lag and logarithmic transformation of the key explanatory variables are employed.

$$
\begin{aligned}
\text { MATURITYDE }_{\mathrm{it}}= & \text { LnCAMEL }, \text { and ZSCORE }_{\mathrm{it}-1}^{\prime} \beta+\gamma_{1} \text { SIZE }_{\mathrm{it}-1}+\gamma_{2} \text { LnLOAN }_{\mathrm{it}-1} \\
& +\gamma_{3} \text { EXPOSURE }_{\mathrm{it}-1}+\gamma_{4} \mathrm{CETES}_{\mathrm{t}}+\text { BANK }_{\mathrm{t}}^{\prime} \alpha+T_{\mathrm{t}}^{\prime} \tau+u_{\mathrm{it}}
\end{aligned}
$$

The Model (4) also includes the control variables SIZE, LOAN, EXPOSURE, CETES, BANK, and $T$, and as in previous cases the CAMEL indicators and $Z$ SCORE are included with caution because of collinearity. The central hypothesis of interest is that MATURITYDE is lower (a shift from long- to short-term deposits) for banks showing low-quality bank fundamentals. MATURITYDE depends positively upon the level of CAPITALR, RESERVE, ROA, ROE and LIQUIDITY1-2 and inversely upon the level of DOUBTFUL and MANAGEMENT1-2. This is interpreted as evidence of market discipline through the maturity mechanism.

Table 4 summarizes the main results. In general, the reported estimations pass the Sargan and the order serial correlation tests, in particular the second order. The lagged dependent variable as regressor presents positive and significant coefficients only in the complete sample, that is, the shift to long-term agreements depends positively on previous long-term agreements.

In the complete sample (columns 1-6), the regressions show weak evidence in favor of the maturity-based mechanism of market discipline. The indicators of asset quality (RESERVE and DOUBTFUL) enter in the model with the predicted sign and statistical significance. In addition, LIQUIDITY1 and 2 have some significant coefficients with the expected sign, and ROE presents significance and the expected sign, but without robustness, note that ROA is impacting in the opposed direction.

CAPITALR and MANAGEMENT2 show evidence against the market discipline hypothesis, that is, banks with low efficiency and lower capital ratios are able to 


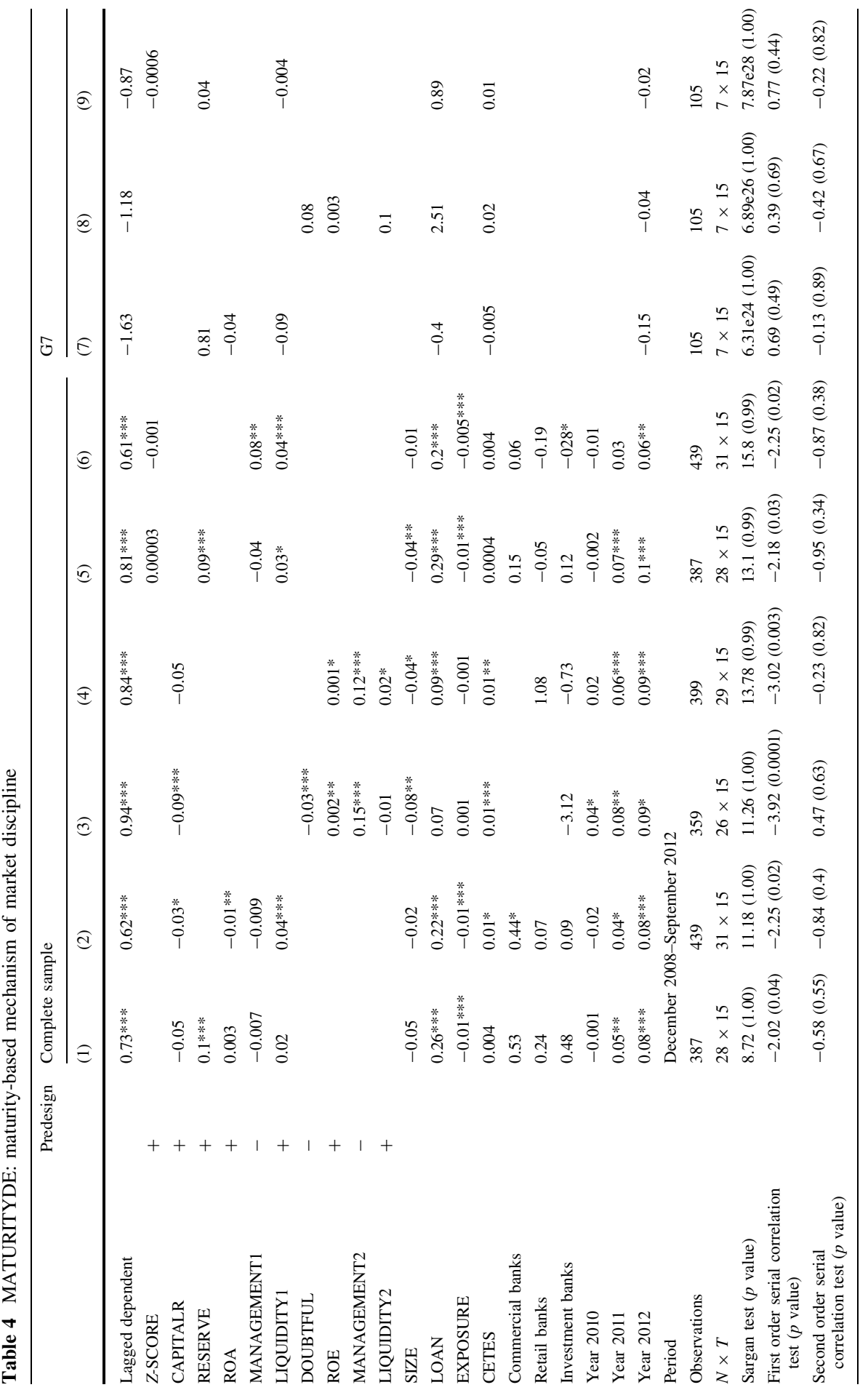




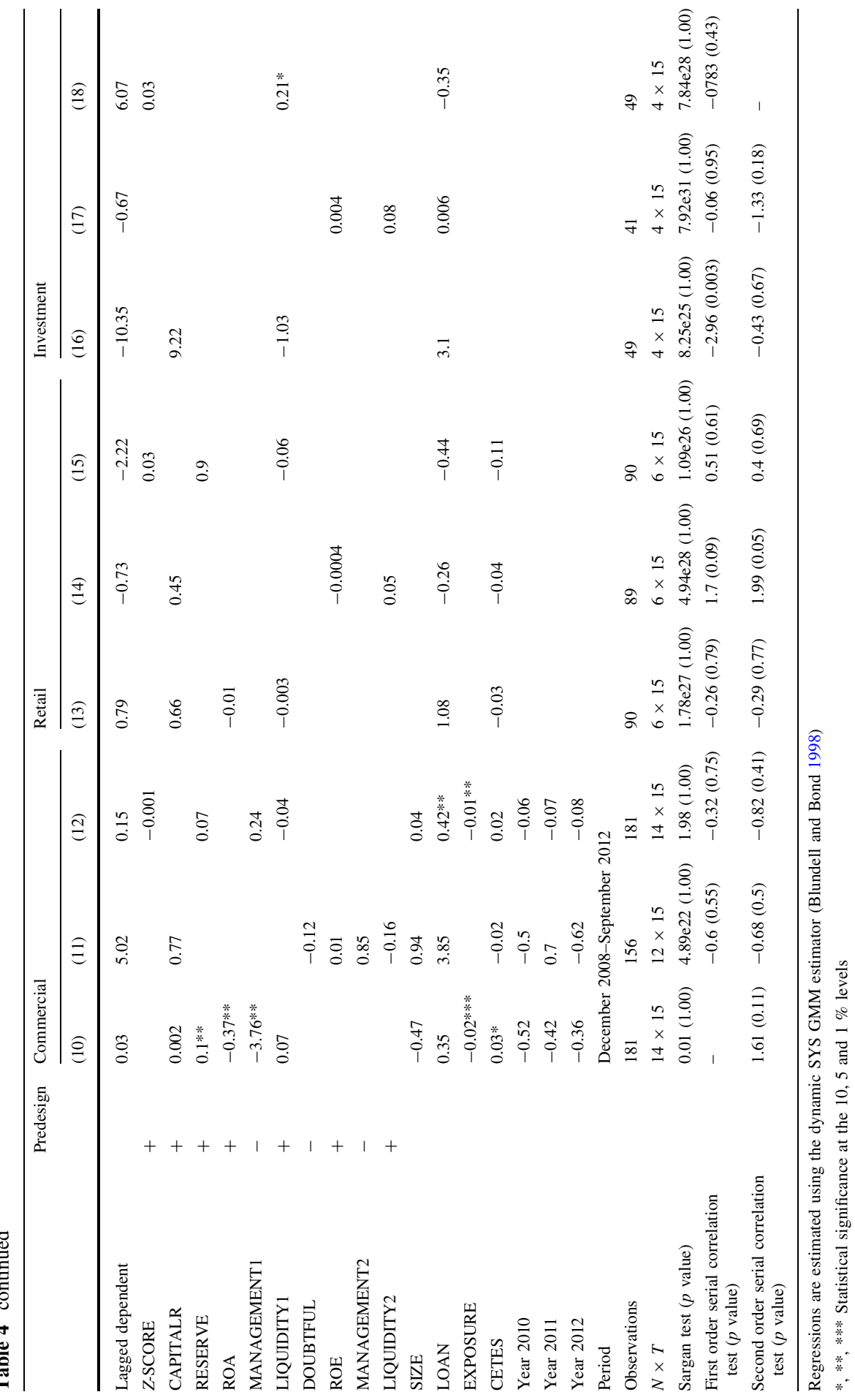


attract more long-term deposits, although this result is not robust, note that MANAGEMENT1 and CAPITALR are not significant in some regressions. In addition, the risk of insolvency ( $Z$ SCORE) does not have statistical significance.

SIZE presents some negative and significant coefficients, that is, larger banks attract fewer long-term deposits. LOAN presents positive and statistical significant coefficients, that is, loan growth positively influence the shift from short- to longterm deposits. EXPOSURE has negative and significant coefficients, note that usually the interbank deposits are short term, and they affect negatively on retail long-term deposits. CETES presents positive and significant coefficients, that is, higher CETES rates favor long-term deposits.

Once more, by subsamples, the model lost its meaning; see columns (7-18) in Table 4. Only commercial banks present some significant coefficients, without robustness. The subsample of investment banks is included with data limitations, the sample only includes four banks, and there is no evidence of market discipline.

Unexpectedly, in the Models (2-4) across subsamples, the majority of coefficients of the explanatory variables are not statistically significant, and they are different (probably due to large differences on bank characteristics by bank groups). This may mean that the regressions using the complete sample with additive dummies for type of bank are not satisfactory, and we are learning very little from this exercise. Nevertheless, the models include other control variables and the results are robust to the inclusion of other explanatory variables. As a result, the findings suggest the lack of market discipline by market sectors, principally.

\section{Conclusions}

The banking literature argues that depositors, through market forces, can discipline the risky behavior of banks. Riskier banks should pay higher interest rates on deposits (price-based mechanism of market discipline), and should attract fewer deposits in comparison with high-quality banks (quantity-based mechanism). Furthermore, riskier banks should show more short-term deposit agreements than long-term (maturity-based mechanism), and vice versa.

In general, previous empirical studies for many different countries show evidence in favor of the market discipline hypothesis. In Mexico, Martinez-Peria and Schmukler (2001) found evidence of market discipline in the deposit market during 1990s, principally after the Tequila crisis in 1994 and 1995. This paper also studied the Mexican case from December 2008 to September 2012, under the conditions of the global financial crisis originating in the USA and Europe. With a regression analysis (dynamic panel model) and a large range of explanatory variables to check robustness, I found weak evidence of market discipline.

The analysis of the price-based mechanism of market discipline indicates that banks showing a lower risk of insolvency (higher values of Z SCORE) pay lower 
interest rates on deposits, in accordance with the market discipline hypothesis. In addition, there are some findings suggesting that banks with good levels of capital, earnings, and liquidity pay lower interest rates. However, in opposition to the market discipline hypothesis, banks showing low administrative efficiency (MANAGEMENT1-2) and low asset quality (RESERVE and DOUBTFUL) pay lower interest rates on deposits.

Through the quantity mechanism, banks with higher capital ratios (CAPITALR) attract more deposits, as the market discipline hypothesis predicts. However, banks with low efficiency (MANAGEMENT1-2) and liquidity problems (LIQUIDITY1-2) can also attract more deposits.

The maturity mechanism shows that banks with high asset quality (RESERVE and DOUBTFUL) are able to attract more long-term deposits, in favor of the market discipline hypothesis. On the contrary, there are also some findings suggesting that banks with low efficiency (MANAGEMENT2) and lower capital ratios (CAPITALR) are able to attract more long-term deposits.

Consequently, considering the complete banking system, mixed results were found. It seems that Mexican banks face market discipline, and depositors do not particularly consider managerial skills as relevant proxies of bank risk to exert market discipline. In addition, the findings suggest that banks can counterattack market discipline with combinations of price, quantity, and maturity of deposits. For example, if a bank confronts market discipline by paying higher interest rates on deposits due to its low capital ratios, this bank can lessen this discipline attracting more long-term deposits anyway. Similarly, if a bank pays higher interest rates on deposits due to a high risk of insolvency, this risk does not influence the quantity of attracted deposits and their maturity.

Furthermore, in the analysis of bank subsamples (G7, commercial, retail and investment banks) the models lost meaning, and practically nothing explained interest rates on deposits, the amount of attracted deposits and their maturities. In other words, a depositor comparing banks by market sectors is not able to demand higher interest rates, reduce the amount of deposits, or shift its deposits to short-term deposits in order to discipline banks.

The findings suggest that banks clearly delimited their markets and within their own market share market discipline is absent. On the one hand, depositors take into account some banks fundamentals to decide where, how long, how much and which price they demand for their deposits. On the other hand, within market sectors, in reality there are no options, and the banks do not confront market discipline, probably because of lack of competition. As a result, policymakers should develop conditions for competition, providing better information on market conditions to depositors by disclosing information about key individual bank characteristics, in accordance with the third pillar of Basel III.

These findings differ from those reported in Martinez-Peria and Schmukler (2001), where in under a new context the deposit insurance is limited, and as a result, it should be friendly with market discipline. Nevertheless, note that the 
variable SIZE (the logarithm of total assets) is statistically significant in many cases, suggesting an implicit "too-big-to-fail" policy.

It is possible that depositors lost interest in monitoring banks due to government intervention, even during crises. It is well known that regulatory discipline (as a deposit insurance) weakens market discipline. Therefore, policymakers must develop a regulatory framework where depositors can weigh the risk of their decisions in the deposit market. In other words, the weak evidence of market discipline may be a consequence of incorrect signals from the monetary authorities; likely Mexican bankers and depositors think that the government will take action in accordance with the implicit "too-big-to-fail" policy.

Actually, most of the risks to the stability of the deposit market in Mexico depend on regulatory discipline. Bureaucrats are responsible for monitoring and controlling bank risk behavior, and under the pressure of interest groups, corruption and external shocks, the main task of Mexican policymakers is to restore market discipline in the deposit market, sending clear signals to the market about government involvement in the case of bank failure.

It is relevant to note that transaction costs (and other institutional variables) affect the elasticity of deposits. Larger depositors (with better financial education) may easily move their deposits, presenting a high elasticity to bank risk, and low transaction costs. Nevertheless, the regressions show low elasticities, despite the global financial crisis, and consequently future research is necessary to re-evaluate the wake-up call proposed by Martinez-Peria and Schmukler (2001) and the effect of institutional variables as transaction costs.

This study presents data limitations, especially for investment banks. Therefore, future research for Mexico must attempt to investigate market discipline including in the sample more investment banks, using data that directly measure the dependent and explanatory variables, and surveys capturing information from depositors. In addition, further research is required to examine competition by groups of banks (G7, commercial, retail and investment banks), because the findings of this investigation suggest that market discipline is absent principally in market sectors.

Open Access This article is distributed under the terms of the Creative Commons Attribution License which permits any use, distribution, and reproduction in any medium, provided the original author(s) and the source are credited.

Acknowledgment The author thanks two anonymous reviewers for their helpful comments and valuable suggestions on earlier versions of this article.

\section{Appendix}

See Appendix Table 5, 6 


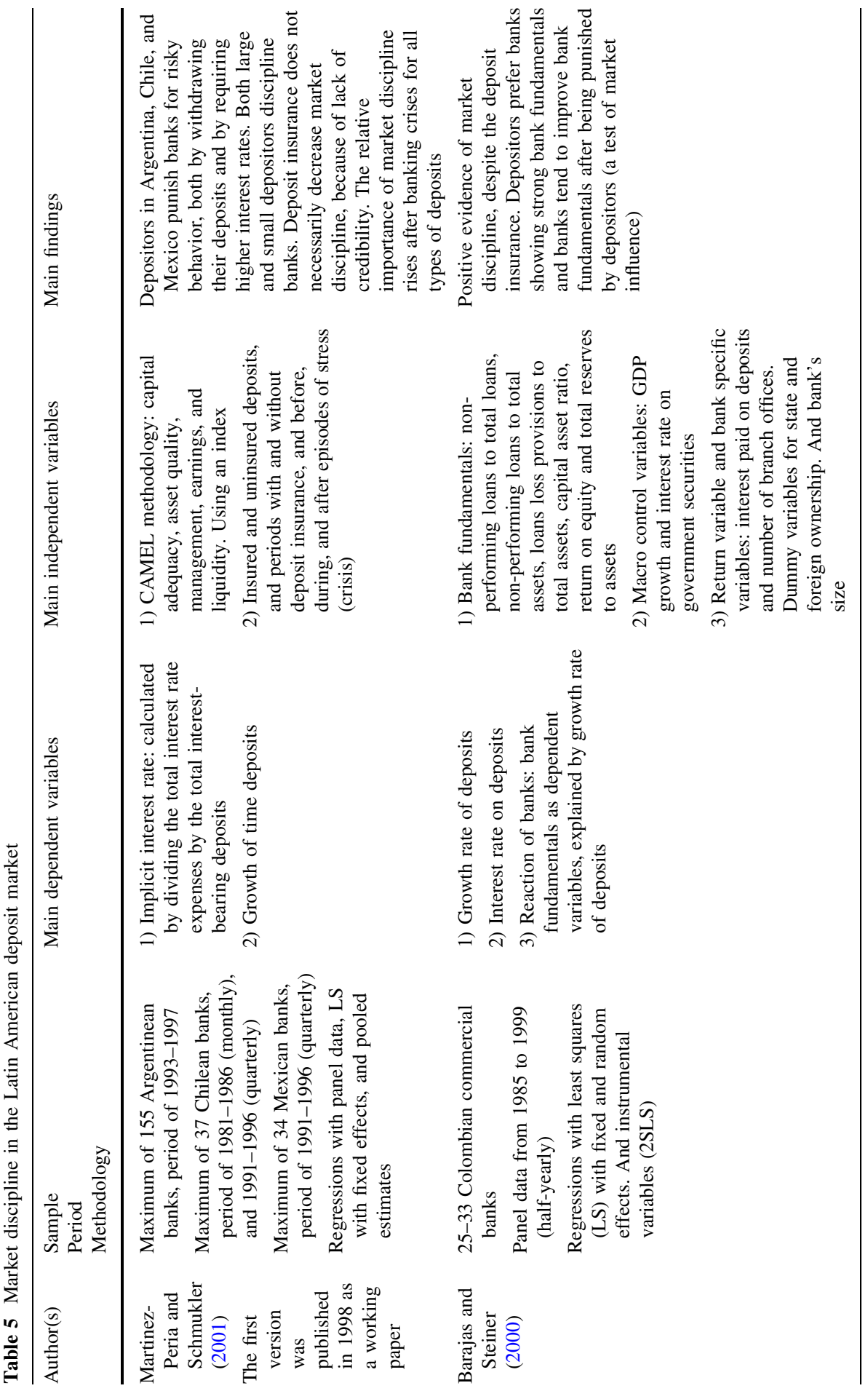




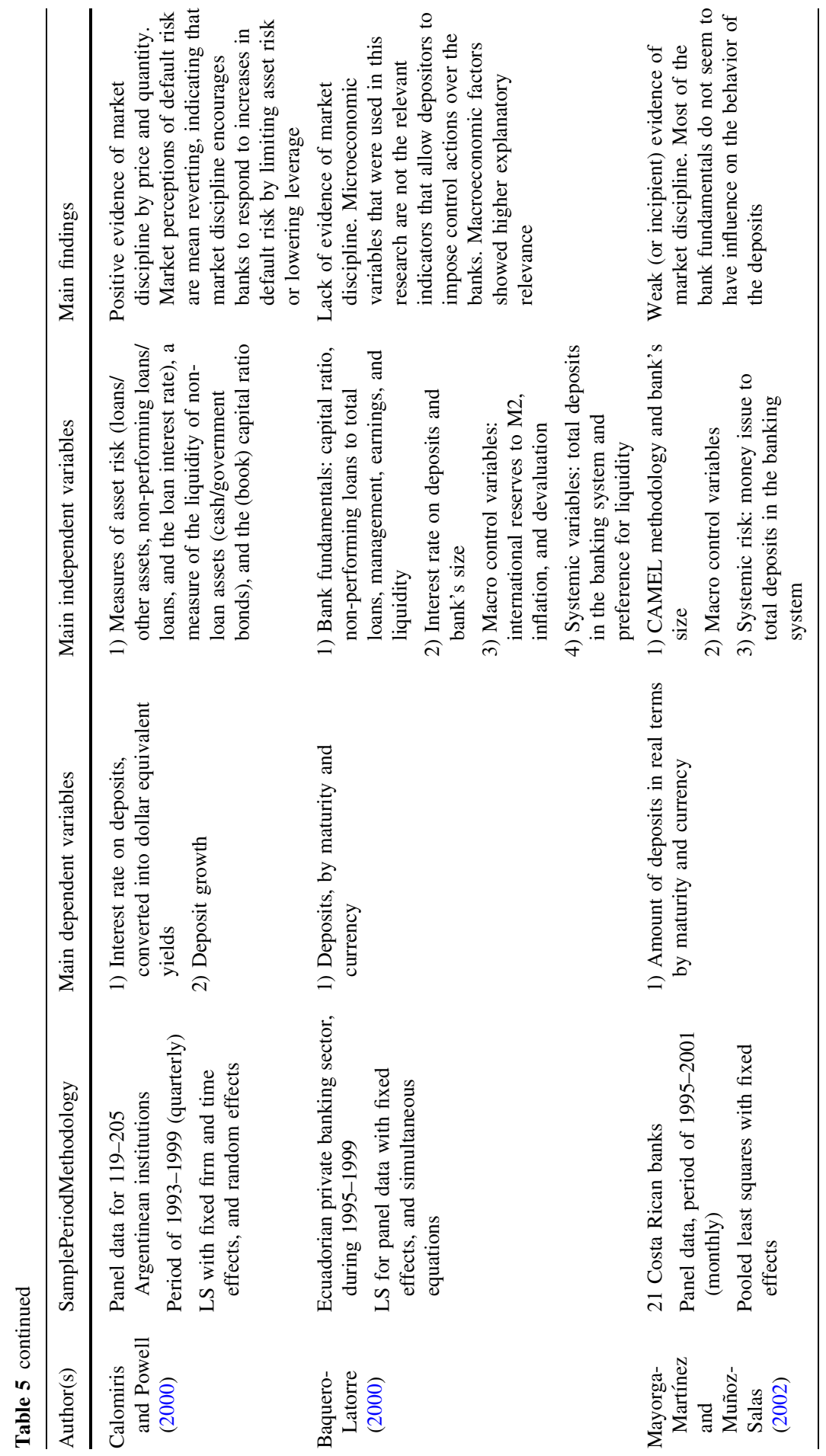




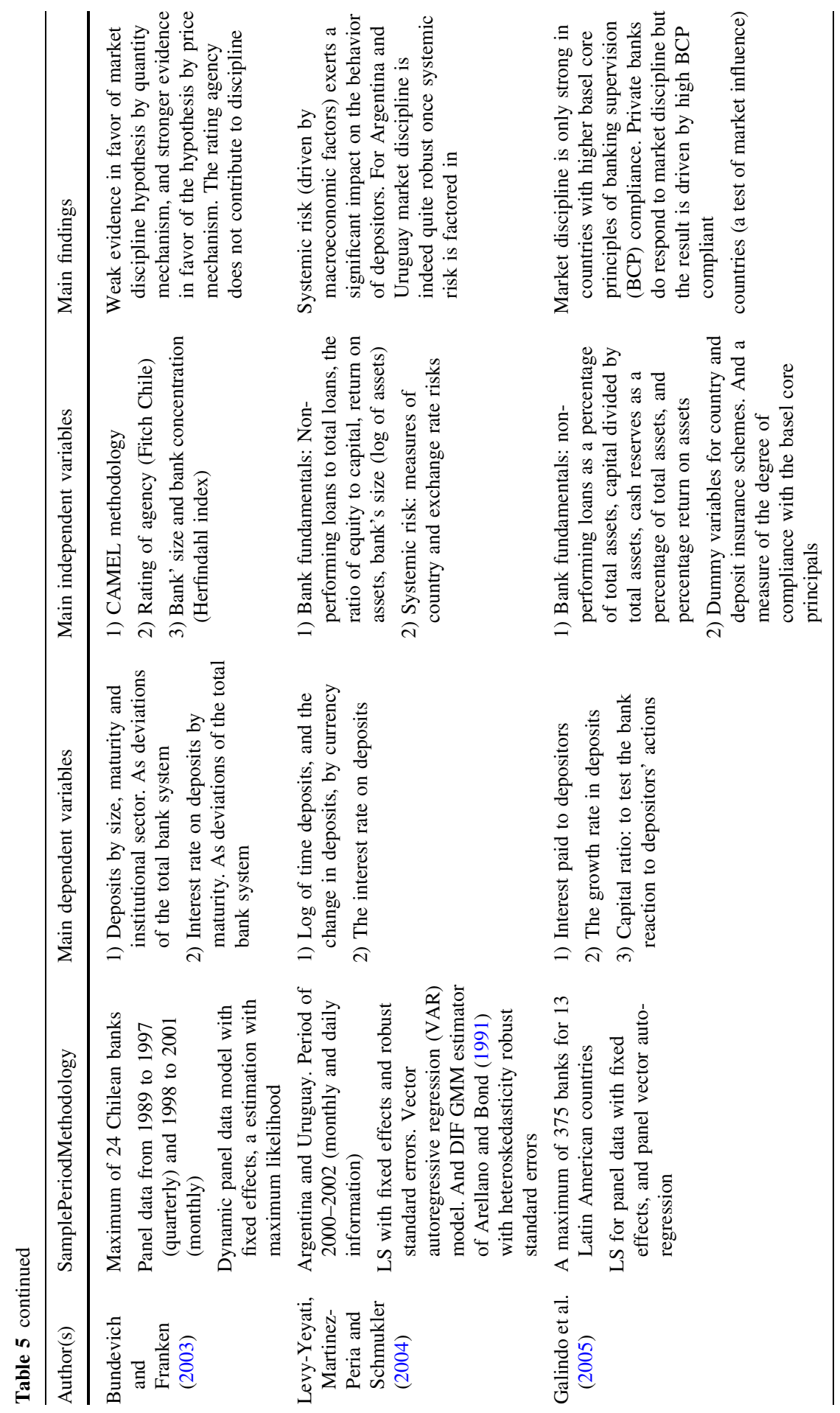




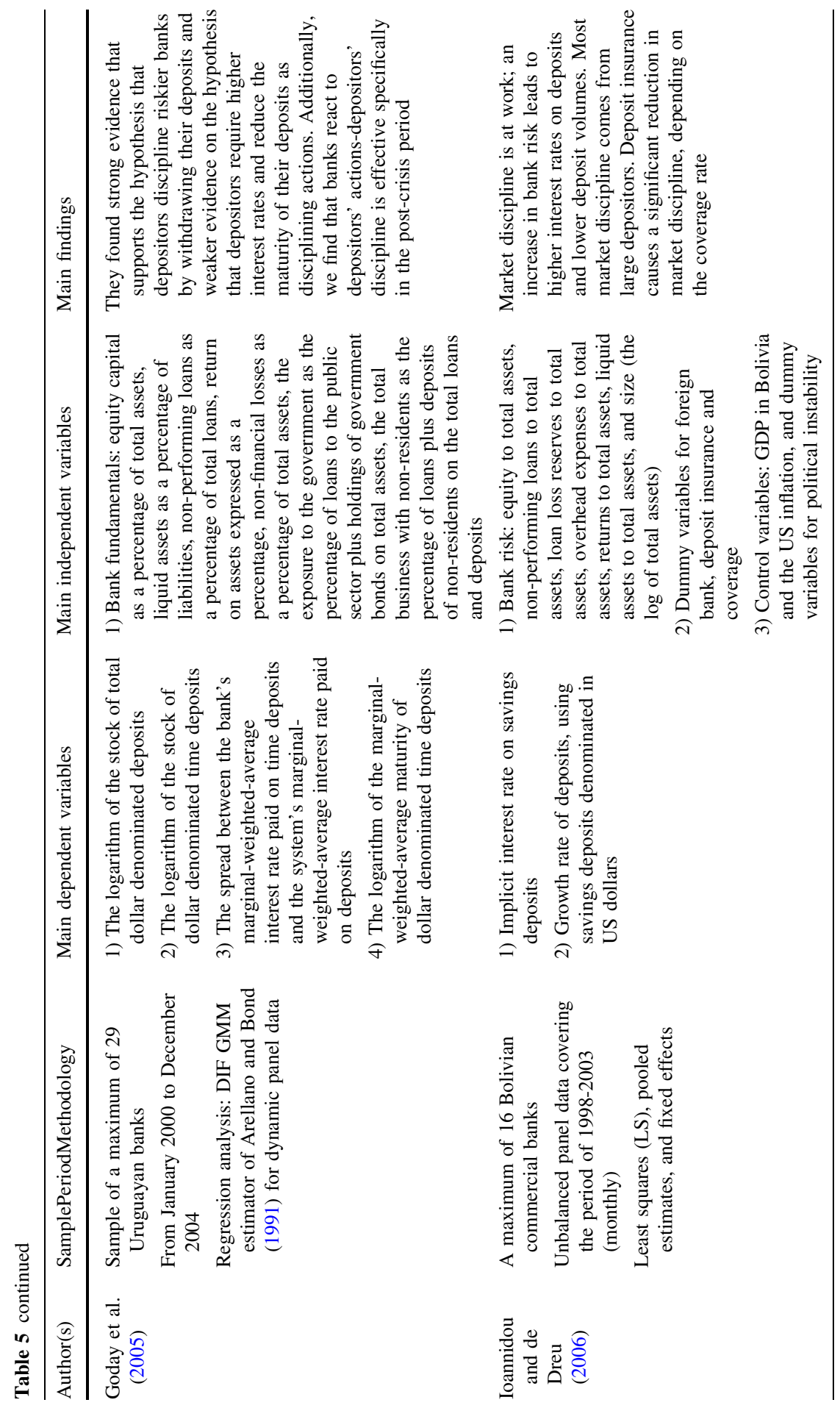




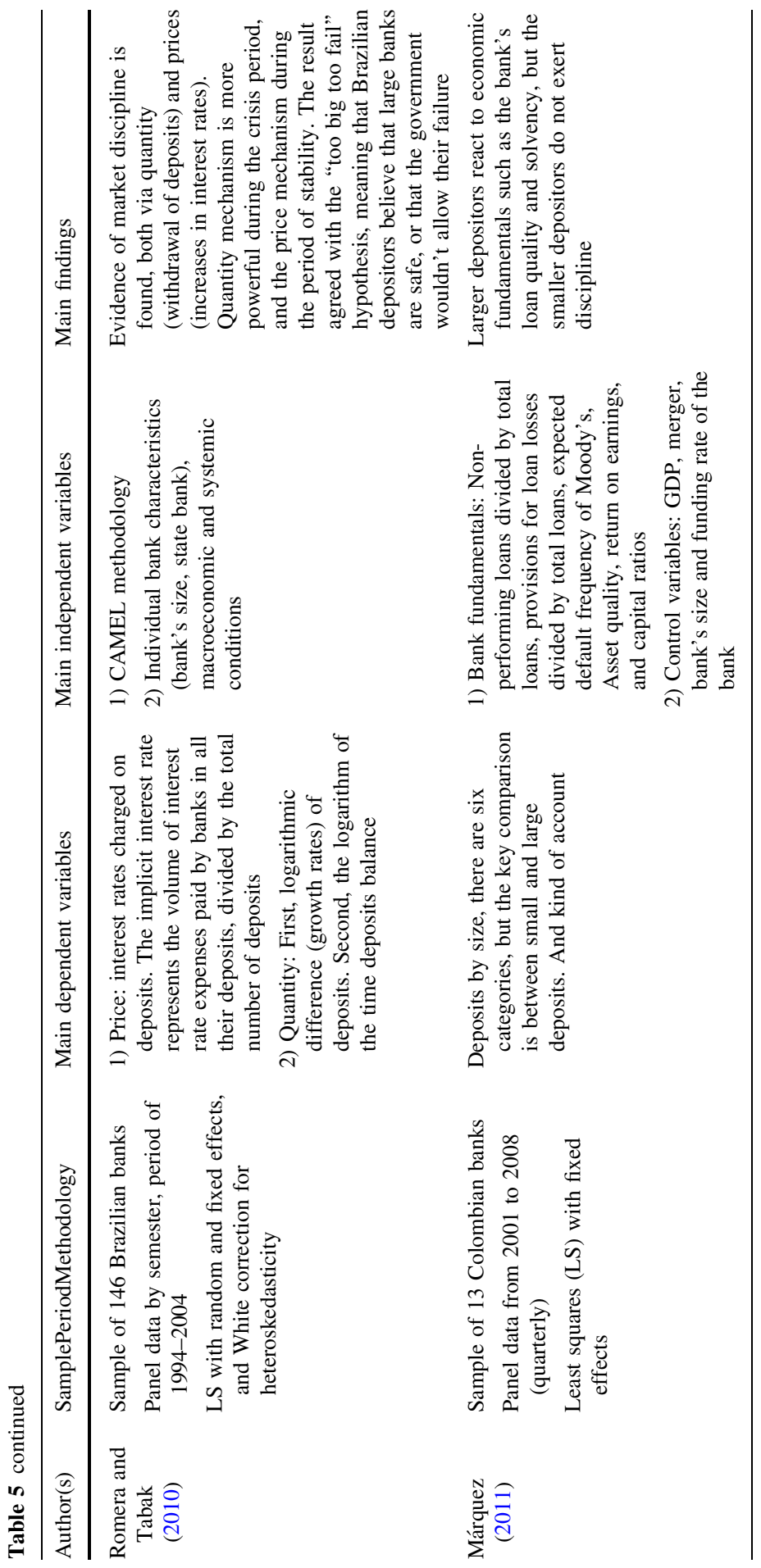

\section{算 Springer}




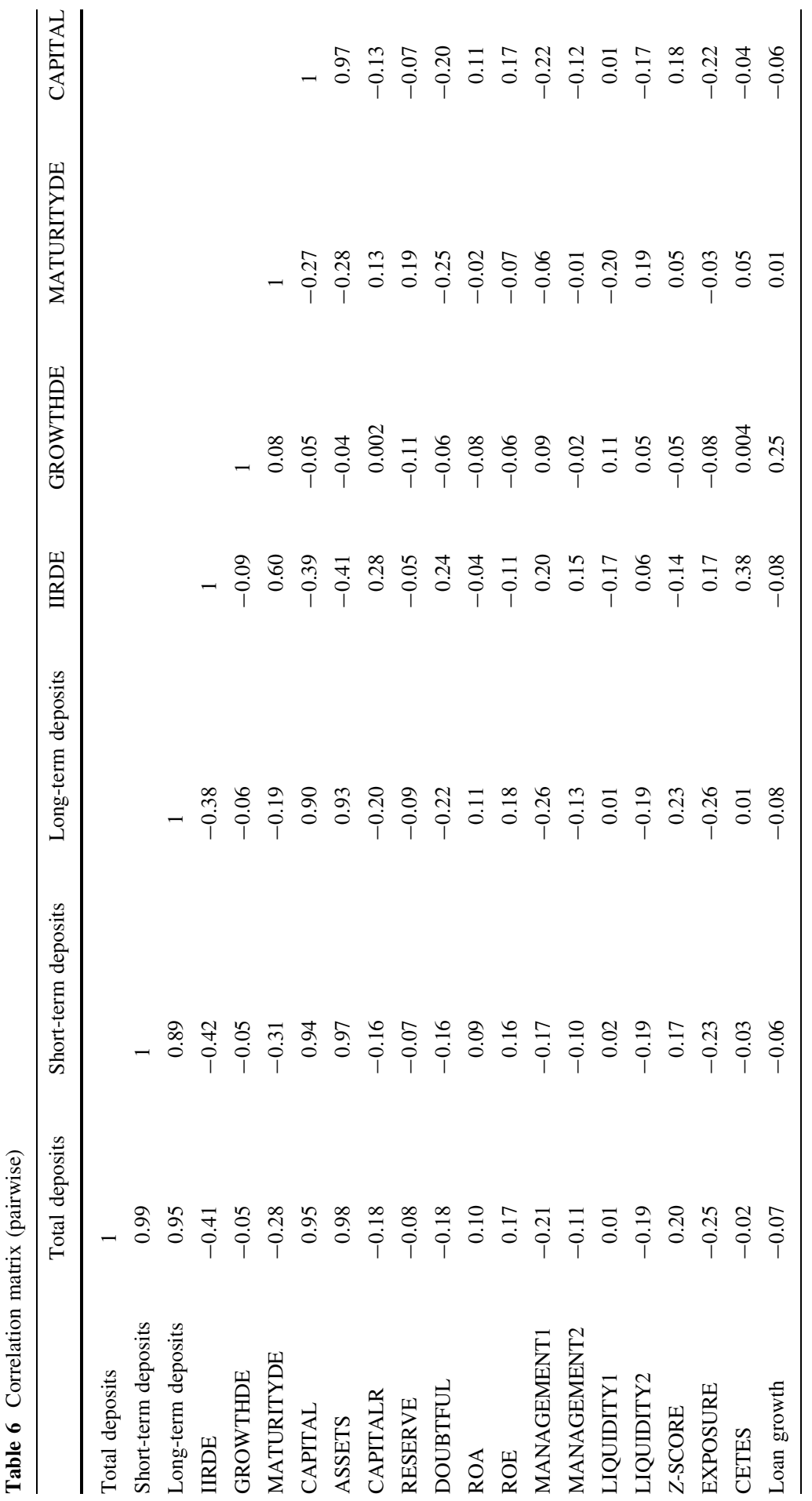




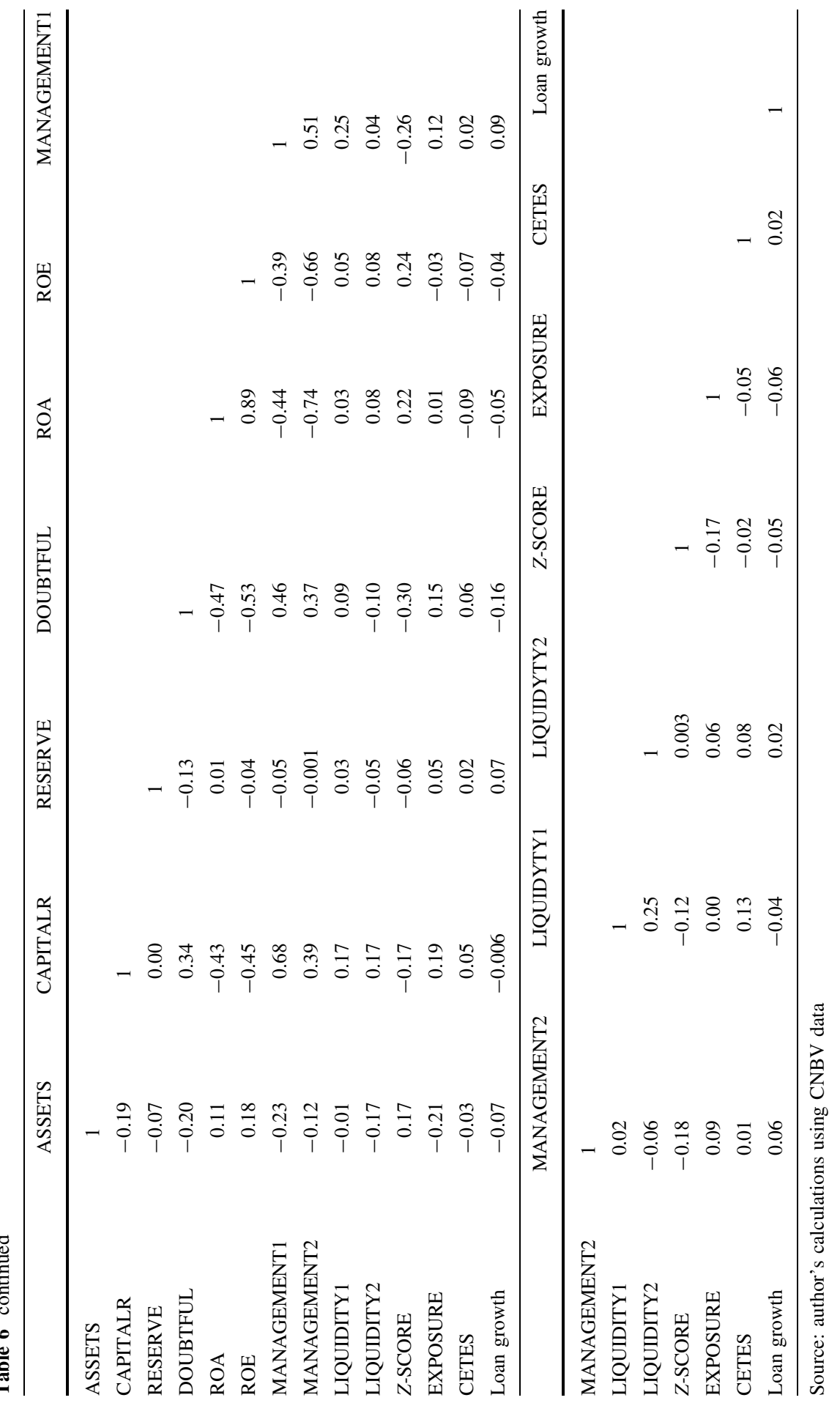



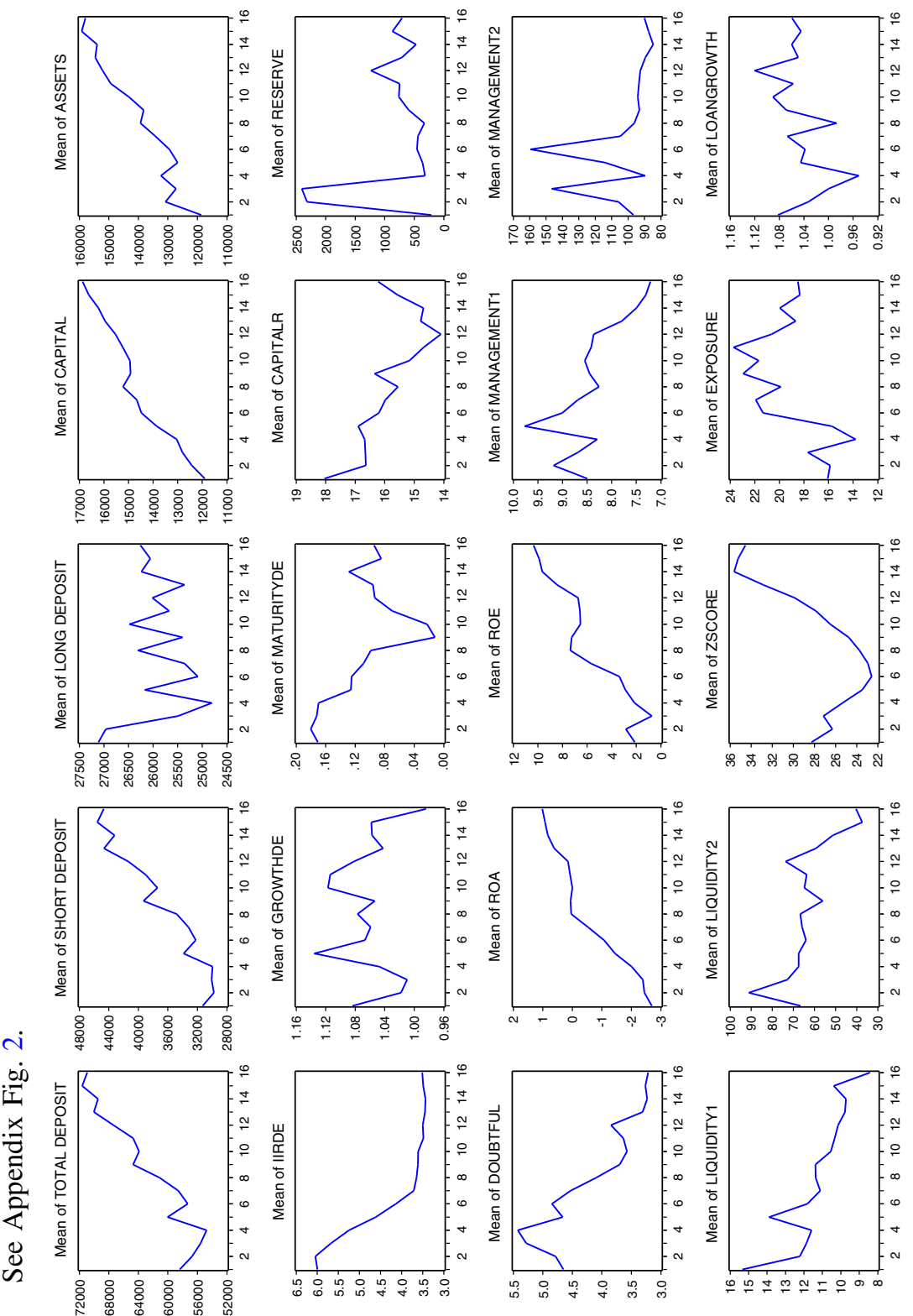

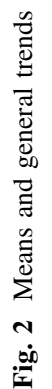




\section{References}

Arellano M, Bond S (1991) Some tests of specification for panel data: Monte Carlo evidence and an application to employment equations. Rev Econ Stud 58(2):277-297

Baquero-Latorre MA (2000) Disciplina de mercado en la banca ecuatoriana: evidencia con datos de panel. Dirección de Investigaciones Económicas, Banco Central del Ecuador. Available via CEMLA, http://www.cemla.org/old/pdf/v_red_baquero.PDF. Accessed 08 Oct 2013

Barajas A, Steiner R (2000) Depositor behavior and market discipline in Colombia. IMF working paper no. 00/214. Available via IMF, http://www.imf.org/external/pubs/ft/wp/2000/wp00214.pdf. Accessed 08 Oct 2013

Ben-David I, Palvia A, Spatt C (2013) Banks' internal capital markets and deposit rates. Working paper. Available via Fisher College of Business, OSU http://fisher.osu.edu/supplements/10/12706/ 20131203_Deleveraging\%20writeup.pdf Accessed 10 Feb 2014

Blundell R, Bond S (1998) Initial conditions and moment restrictions in dynamic panel data models. J Econ 87:115-133

Bundevich LC, Franken MH (2003) Disciplina de mercado en la conducta de los depositantes y rol de las agencias clasificadoras de riesgo: El caso de Chile. Econ Chil 6(2):45-70

Calomiris CW (1999) Building an incentive-compatible safety net. J Bank Financ 23:1499-1519

Calomiris CW, Powell A (2000) Can emerging market bank regulators establish credible discipline? The case of Argentina, 1992-1999. NBER working paper no. 7715. Available via NBER, http://www. nber.org/papers/w7715. Accessed 08 Oct 2013

Demirguc-Kunt A, Huizinga H (2004) Market discipline and deposit insurance. J Monet Econ 51:375-399

Diamond DW, Dybvig PH (1983) Bank runs, deposit insurance, and liquidity. J Polit Econ 91(3):401-419

Distinguin I, Kouassi T, Tarazi A (2013) Interbank deposits and market discipline: evidence from Central and Eastern Europe. J Comp Econ 41(2):544-560

Flannery M (2001) The faces of market discipline. J Financ Serv Res 20(2/3):107-119

Galindo A, Powell A, Loboguerrero AM (2005) Latin American banks, market discipline and official regulation: completing the circle. Working paper, inter American Development Bank. Available via SSRN, http://ssrn.com/abstract=712883. Accessed 08 Oct 2013

Goday V, Gruss B, Ponce J (2005) Depositors' discipline in Uruguayan banks. Documento de Trabajo No. 003-2005, Banco Central del Uruguay. Available via http://www.bvrie.gub.uy/local/File/ doctrab/2005/3.2005.pdf. Accessed 08 Oct 2013

Huybens E, Luce JA, Pratap S (2005) Financial market discipline in early-twentieth-century Mexico. J Econ Hist 65(3):757-778

Ioannidou V, de Dreu J (2006) The impact of explicit deposit insurance on market discipline. CentER discussion paper No. 2006-05. Available via SSRN, http://ssrn.com/abstract=888681. Accessed 08 Oct 2013

Levy-Yeyati E, Martinez-Pería M, Schmukler S (2004) Market discipline under systemic risk: evidence from bank runs in emerging economies. Working paper 02/2004, Universidad Torcuato Di Tella. Available via http://www.utdt.edu/departamentos/empresarial/cif/pdfs-wp/wpcif-022004.pdf. Accessed 08 Oct 2013

Luce JA (2000) Seguros bancarios y disciplina de mercado aplicación a la crisis financiera de 1907 en México. Gaceta de Econ 5(10):121-152

Márquez AJ (2011) El seguro de depósito y su incidencia en la disciplina de mercado en Colombia. Coyunt Econ Investig Econ Soc 41(2):87-117

Martinez-Peria M, Schmukler S (2001) Do depositors punish banks for bad behavior? Market discipline, deposit insurance, and banking crises. J Financ 56:1029-1051

Mayorga-Martínez M, Muñoz-Salas E (2002) ¿Existe disciplina de mercado en el sistema bancario costarricense? Econ Soc 20:61-100

Murata K, Hori M (2006) Do small depositors exit from bad banks? Evidence from small financial institutions in Japan. Jpn Econ Rev 57:260-278

Park S (1995) Market discipline by depositors evidence from reduced form equations. Q Rev Econ Financ 35:397-513

Park S, Peristiani S (1998) Market discipline by thrift depositors. J Money Credit Bank 30:337-363

Romera MP, Tabak BM (2010) Testing for market discipline in the Brazilian banking industry. Banks Bank Syst 5(3):112-128 
Semenova M (2007) How depositors discipline banks: the case of Russia. Economics education and research consortium working paper No. 07/02. Available via http://publications.hse.ru/books/ 80871392. Accessed 08 Oct 2013

Tovar-García ED (2012) Market discipline in Mexican banks: evidence from the asset side. Cuad Econ Span J Econ Financ 35(99):172-181 